\title{
PORCELAIN PRODUCT QUALITY ANALYSIS IN PT XYZ
}

\author{
Ho Hwi Chie'; Januar Nasution²; Ketut Gita Ayu; \\ Nike Septivani ${ }^{4}$; Yualfin Renaldi ${ }^{5}$ \\ Industrial Engineering Department, Faculty of Engineering, BINUS University \\ Jl. K.H. Syahdan No. 9 Jakarta Barat \\ ${ }^{1}$ hhchie@binus.edu, 2januar_nasution3000@yahoo.com, \\ 33gayu@binus.edu, 4nseptivani@binus.edu, 5yualfinrenaldi@gmail.com
}

\begin{abstract}
PT. XYZ is a company engaged in manufacturing porcelain dinner ware such as plates, cups, teapot, bowl, etc Porcelain product is safe for use and product defect will only affect the aesthetic not the functional side. The company always maintain the quality of the products produced as by maintaining a good product, in terms of visuals, will keep customers interested in the product. Good quality products characterized by quality A I $B$ and $C$, and the product defect characterized by the quality of $D$, Lost, and BU. Concepts and methods used to analyze is a statistical process control (SPC) which includes Pareto diagram, fraction nonconformities, flow charts and fishbone diagrams and management tools (fault tree analysis). Statistical Process Control (SPC) is one of the methods, which includes Pareto charts, fraction nonconformities, flow chart, and fishbone diagram and also management tools (fault tree analysis). SPC is useful to find the facts from the problems and factors that affect the quality of the products, while fault tree analysis is useful to analyze each of the production process.
\end{abstract}

Keywords: quality, rework, defect

\begin{abstract}
ABSTRAK
PT XYZ merupakan salah satu perusahaan yang bergerak di bidang manufaktur porcelain dinner ware seperti piring, gelas, teapot, bowl, dsb. Porcelain yang diproduksi aman untuk digunakan dan produk defect hanya akan mempengaruhi sisi aesthetic bukan sisi fungsional. Perusahaan selalu menjaga kualitas produkproduk yang dihasilkan karena dengan menjaga produk yang baik dari segi visual akan membuat pelanggan tertarik terhadap produk tersebut. Kualitas produk yang baik ditandai dengan kualitas A/B dan C, dan produk defect ditandai dengan kualitas $D$, Lost, dan BU. Konsep dan metode yang digunakan untuk menganalisa adalah statistical process control (SPC) yang meliputi pareto diagram, fraction nonconformities, flow chart, dan fishbone diagram, serta management tools (fault tree analysis). Dengan adanya SPC didapat beberapa fakta mengenai permasalahan kualitas dan faktor-faktor yang ada, dan dengan menggunakan fault tree analysis, dapat dilihat secara jelas kejadian-kejadian yang mempengaruhi masalah kualitas yang ada, sehingga dapat mengetahui keseluruhan proses serta hambatan-hambatan yang dihadapi.
\end{abstract}

Kata kunci: kualitas, rework, defect 


\section{PENDAHULUAN}

PT XYZ merupakan perusahaan yang bergerak di bidang peralatan alat makan yang terbuat dari bahan porcelain. Peralatan makan ini digunakan hampir seluruh masyarakat, oleh karena itu produk harus terbuat dari bahan yang aman untuk digunakan. Peralatan yang terbuat dari plastik cenderung tidak aman meskipun memiliki kualitas food-grade karena plastik akan mengalami degradasi ketika peralatan tersebut dipakai untuk makanan yang panas (Administrator Siaran Pers, 2009). Masih banyak ditemukan peralatan makan yang masih menggunakan peralatan makan berbahan plastik (melamine) bahkan dengan kondisi yang kurang bagus. Peralatan yang diproduksi oleh PT XYZ ini terbuat dari keramik (porcelain), sehingga sangat aman untuk digunakan sebagai alat makan.

Peralatan makan yang diproduksi aman untuk digunakan dan produk defect hanya akan mempengaruhi sisi aesthetic saja bukan dari sisi fungsional. Perusahaan selalu menjaga kualitas produk-produk yang dihasilkan karena dengan menjaga produk yang baik dari segi visual akan membuat pelanggan tertarik terhadap produk tersebut. Oleh karena itu, perusahaan saat ini menerapkan standar ISO: 90001 sejak tahun 2008. Kualitas produk yang baik ditandai dengan kualitas A/B dan C, dan produk defect ditandai dengan kualitas D, Lost, dan BU. (Myklebust, 2013). Berdasarkan data defect, hal ini menunjukkan quality target tidak terpenuhi karena angka defect masih jauh di atas yang ditetapkan yaitu $2 \%$. Adapun defect yang terjadi dapat berupa total defect yaitu produk tidak memenuhi standar komposisi dari segi bahan baku di awal proses; lost yaitu terdapat satu jenis defect berupa titik atau gelembung; dan BU (bakar ulang) yaitu produk tidak memenuhi standar komposisi hingga akhir proses.

Setelah dilakukan pengamatan pada PT XYZ, maka ada beberapa masalah yang akan diteliti. Pertama, faktor-faktor apa saja yang mempengaruhi terjadinya produk yang cacat? Kedua, dari segi pengendalian kualitas, apa yang dapat ditingkatkan untuk mengurangi angka defect yang tinggi? Untuk mencapai tujuan tersebut, maka tahapan analisis yang dilihat pada gambar 1.

Langkah pengamatan yang tertuang dalam diagram alir pertama adalah observasi lapangan. Observasi ini dilakukan pada bagian pengendalian kualitas dari keseluruhan proses. Kedua, studi pustaka, pada tahap ini dilakukan penentuan metode dan teori, baik dalam bentuk buku maupun jurnal yang akan digunakan dalam proses pengamatan. Adapun beberapa tools yang dipakai, yakni flow chart, pareto diagram, fishbone diagram, fault tree analysis, dan peta kendali $p$. (Rungtusanatham, 2001). Ketiga, perumusan masalah, dari hasil observasi maka dapat ditentukan perumusan masalahnya. Keempat, penentuan tujuan dan manfaat penelitian yaitu menentukan tujuan dan manfaat terkait perumusan masalah kualitas produk porcelain. Kelima, pengumpulan data yaitu dilakukan pengumpulan data terkait permasalahan yang ada pada rumusan masalah. Data-data tersebut diperoleh dari wawancara langsung, data produksi serta data kualitas.

Keenam, pengolahan data, setelah mendapatkan data yang cukup, tahap selanjutnya ialah mengolah data tersebut dengan menggunakan tools yang berkaitan dengan pengendalian kualitas, seperti flow chart dan pareto diagram untuk mengidentifikasi permasalahan yang paling penting dan paling vital yang membutuhkan pengawasan, kemudian ada peta kendali $p$ untuk memperhitungkan rasio sejumlah ketidaksesuaian benda dalam sebuah populasi dari jumlah keseluruhan populasi, serta fault tree analysis untuk menganalisa sistem keamanan dan keandalan yang digambarkan melalui sebuah model yang bergambar dan logis dari hubungan antara kejadian yang tidak diinginkan dengan peristiwa yang lebih mendasar. Ketujuh, hasil dan pembahasan, pada tahap ini, dilakukan analisa terhadap data-data dan informasi yang telah diolah sebelumnya, serta menganalisa permasalahan yang ada dengan gambaran fishbone dan FTA, sehingga dapat membantu menjelaskan mengenai perumusan masalah yang ada terkait permasalahan kualitas. Kedelapan, simpulan merupakan tahap terakhir, yakni memberikan simpulan terkait masalah kualitas yang dibahas dalam pengamatan ini. 


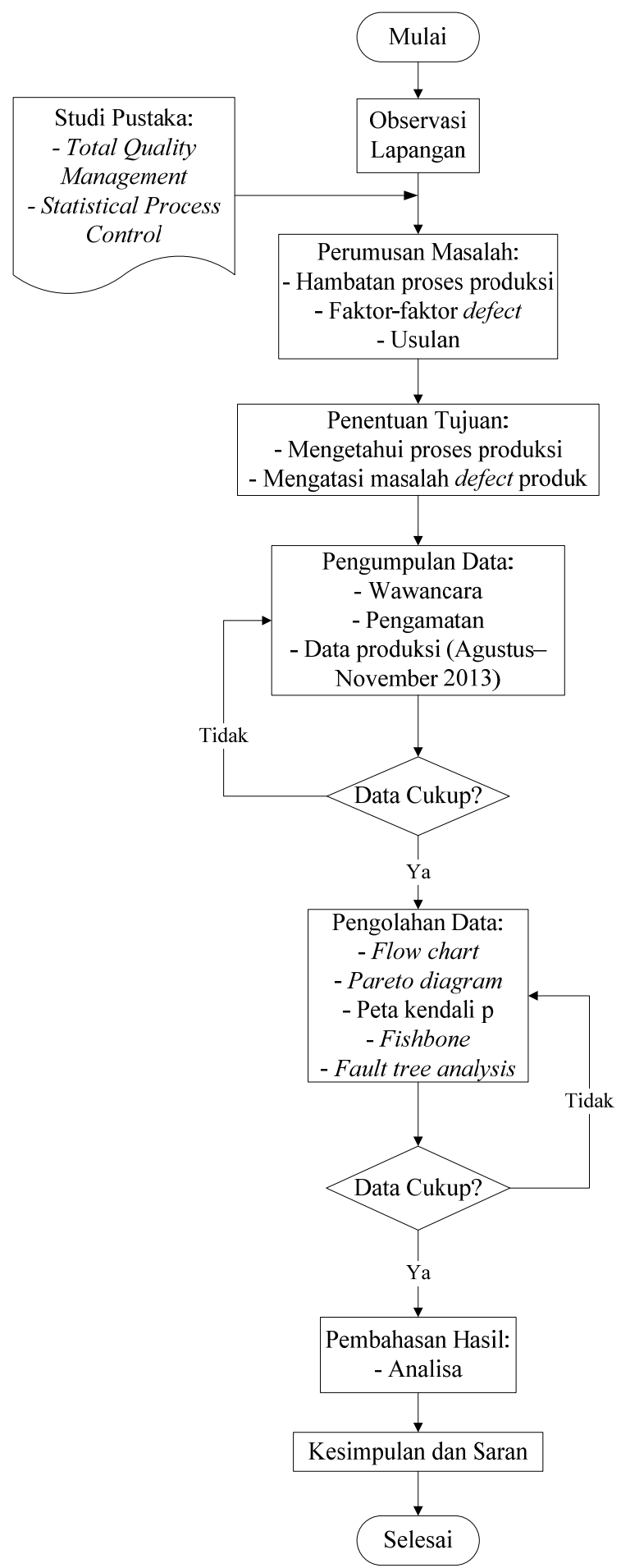

Gambar 1 Diagram Alir 


\section{HASIL DAN PEMBAHASAN}

Setelah mengetahui beberapa proses yang ada dalam pembuatan produk porcelain, ada dua fase yang cukup penting untuk diperhatikan terkait kualitas, yakni pada fase WIP (work in process) dan produk jadi. Berikut ini adalah data jumlah produksi beserta jumlah produk defect yang terjadi pada WIP (Tabel 1), barang jadi (glost ware) (Tabel 2), serta data mingguan mengenai jumlah produk yang tidak sesuai menurut jenis ketidaksesuaiannya (tabel 3).

Tabel 1 Data Jumlah Produksi dan Defect Work in Process Mingguan

\begin{tabular}{cccccc}
\hline Date & Jumlah Produksi & Jumlah Defect & Date & Jumlah Produksi & Jumlah Defect \\
\hline Week 1 & 139,550 & 13,500 & Week 9 & 229,442 & 20,719 \\
Week 2 & 130,248 & 13,944 & Week 10 & 203,576 & 15,974 \\
Week 3 & 141,932 & 15,049 & Week 11 & 199,228 & 13,345 \\
Week 4 & 188,476 & 14,978 & Week 12 & 165,618 & 14,862 \\
Week 5 & 213,420 & 14,156 & Week 13 & 172,652 & 16,311 \\
Week 6 & 222,634 & 19,511 & Week 14 & 203,675 & 16,864 \\
Week 7 & 212,719 & 19,709 & Week 15 & 225,408 & 17,959 \\
Week 8 & 222,672 & 17,210 & & & \\
\hline
\end{tabular}

Sumber: PT XYZ

Tabel 2 Data Jumlah Produksi dan Defect Glost Ware Mingguan

\begin{tabular}{cccccc}
\hline Date & Jumlah Produksi & Jumlah Defect & Date & Jumlah Produksi & Jumlah Defect \\
\hline Week 1 & 108,319 & 7,081 & Week 9 & 198,440 & 16,294 \\
Week 2 & 115,813 & 6,897 & Week 10 & 196,662 & 17,169 \\
Week 3 & 121,958 & 7,667 & Week 11 & 173,553 & 14,010 \\
Week 4 & 159,351 & 10,564 & Week 12 & 165,804 & 12,461 \\
Week 5 & 189,806 & 11,644 & Week 13 & 144,130 & 12,399 \\
Week 6 & 182,713 & 13,073 & Week 14 & 172,959 & 12,304 \\
Week 7 & 175,637 & 14,595 & Week 15 & 220,024 & 25,513 \\
Week 8 & 203,361 & 13,606 & & & \\
\hline
\end{tabular}

Sumber: PT XYZ

Tabel 3 Data Mingguan Jumlah Defect Berdasarkan Jenis Defect

\begin{tabular}{ccccc} 
Date & Iron Spot & Warp Piece & Other & Bakar Ulang \\
\hline week 1 & 2,102 & 1,779 & 1,875 & 8,595 \\
week 2 & 3,898 & 2,534 & 4,877 & 17,316 \\
week 3 & 9,445 & 2,194 & 10,239 & 18,429 \\
week 4 & 8,886 & 4,794 & 11,722 & 19,542 \\
week 5 & 8,754 & 8,077 & 12,861 & 19,542 \\
week 6 & 7,562 & 11,540 & 14,722 & 30,688 \\
week 7 & 11,134 & 4,532 & 13,586 & 26,991 \\
week 8 & 1,526 & 522 & 3,598 & 5,278 \\
\hline \multicolumn{5}{c}{ Sumber: PT XYZ }
\end{tabular}

\section{Pengolahan Data}

Untuk dapat menganalisa proses yang ada dalam perusahaan, pemetaan proses perlu dilakukan dengan menggunakan flow chart, karena dengan menggunakan bagan alur, dapat digambarkan alur proses dari awal hingga akhir. Setelah mengetahui serangkaian proses pembuatan maka perlu diketahui juga jenis ketidaksesuaian yang sering terjadi dalam proses pembuatan produk porcelain ini. Oleh karena itu, diperlukan diagram Pareto untuk melihat seberapa besar kontribusi ketidaksesuaiannya berdasarkan jenis yang ada pada produk barang jadi. 


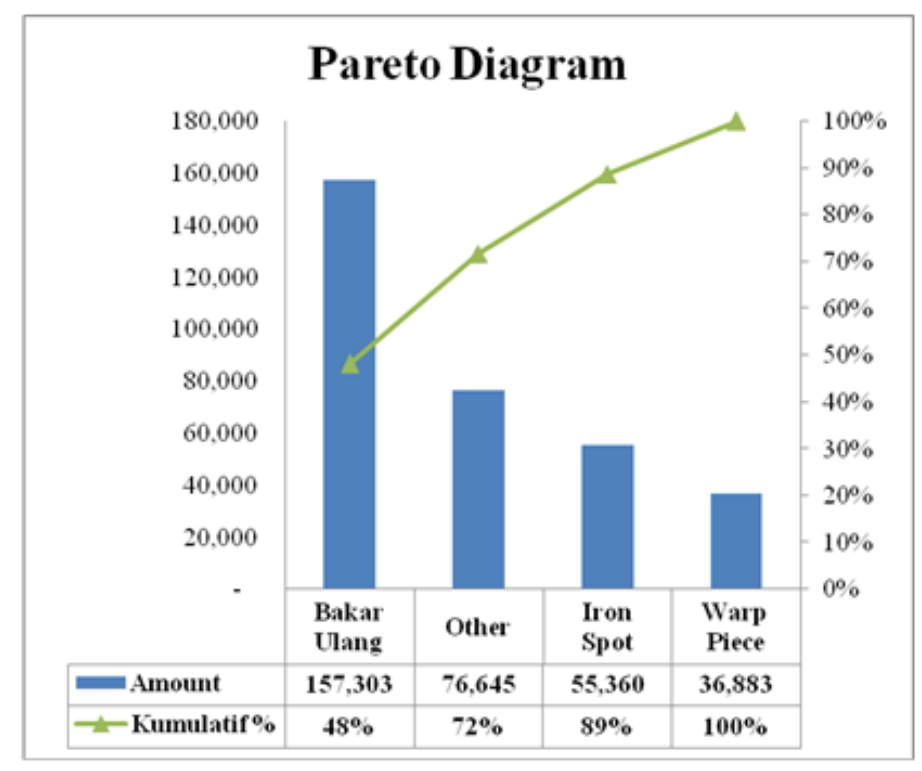

Gambar 2 Pareto Diagram

Tidak hanya melihat dari jenis ketidaksesuaian dari produk, namun perlu dilihat juga dari data produksi produk WIP dan barang jadi (Tabel 1 dan Tabel 2) yang dapat diolah dengan menggunakan peta kendali $p$, guna melihat kestabilan dari proses produksi produk porcelain pada perusahaan ini, sehingga didapat hasil seperti gambar berikut (Montgomery, 2009).

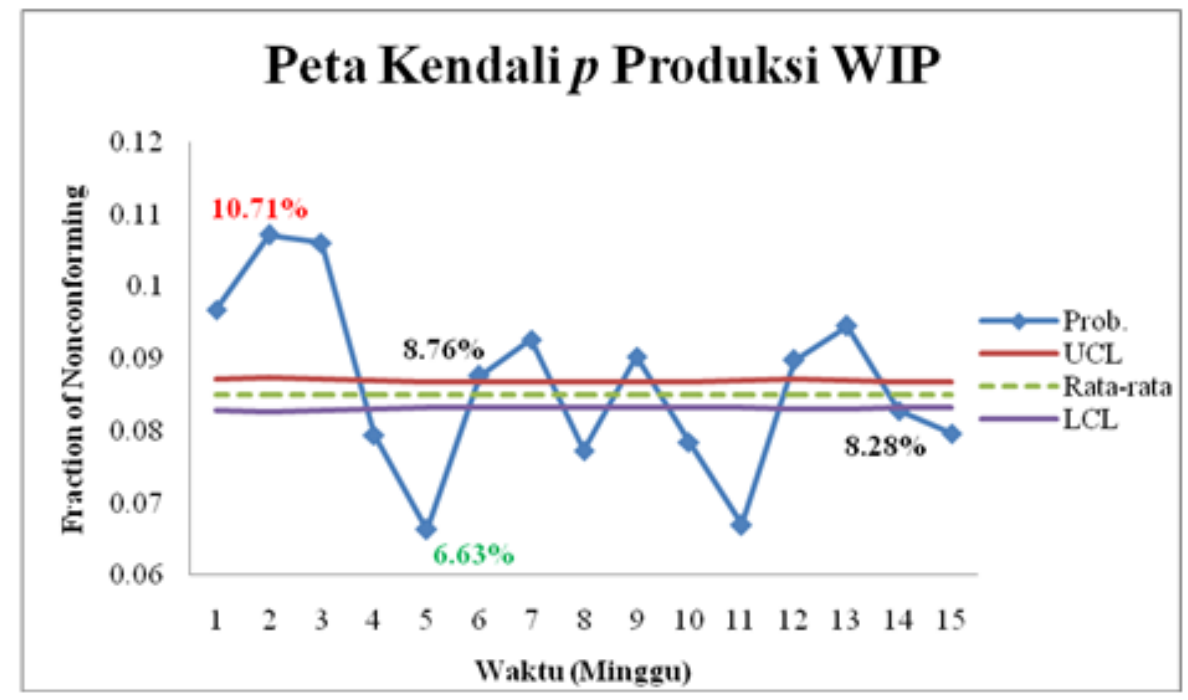

Gambar 3 Peta Kendali p Produksi WIP 


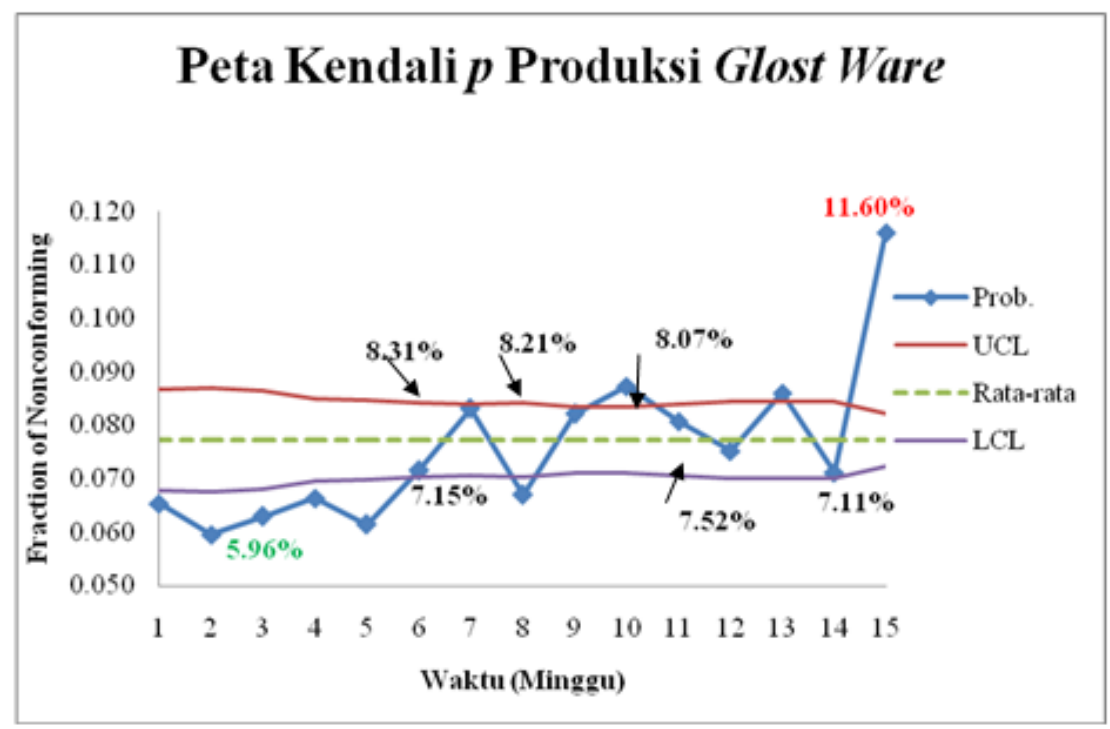

Gambar 4 Peta Kendali $p$ Produksi Glost Ware

\section{Analisa Data}

Keseluruhan proses produksi produk porcelain memiliki alur yang sebagian besar seperti rangkaian seri, bukan paralel. Hal ini yang membuat penelusuran masalah cukup sulit ditemukan karena hasil dari semua proses dipengaruhi oleh setiap proses sebelumnya sehingga sangat memungkinkan sebuah produk mengalami kecacatan karena komposisi bahan yang salah atau kesalahan pembakaran. Ini berarti proses akhir dipengaruhi oleh proses awal atau pertengahan. Kesadaran dan ketelitian dari operator yang menangani setiap proses menjadi suatu hal yang sangat penting, agar ketika suatu kesalahan/cacat produk ditemukan, maka produk yang memiliki masalah ini tidak perlu dilanjutkan ke proses selanjutnya. Setiap proses perlu dibangun dan dikontrol dengan baik untuk menghindari kesalahan yang terus berlanjut yang berdampak negatif bagi perusahaan. Bukan hanya tugas quality control untuk mengatur kualitas secara keseluruhan agar terjaga, namun menjadi suatu tanggung jawab setiap individu yang berperan didalam setiap proses dari awal hingga akhir.

Karena banyak proses dalam pembuatan produk porcelain ini, waktu menjadi hal yang pentingnya demi proses produksi secara terus menerus untuk memenuhi kebutuhan permintaan produk porcelain. Proses produksi dimulai dari pemesanan bahan baku yang memakan waktu cukup lama, membuat desain cetakan, membuat komposisi bahan, pembentukan dan proses pembuatan dapat mencapai waktu satu minggu lebih. Untuk mencapai target pada saat sudah mendekati waktu pengiriman maka pengorbanan pada kualitas produk akan terjadi. Permasalahan waktu proses produksi ini dapat diatasi melalui suatu sistem penjadwalan yang cukup baik, sehingga tidak terjadi proses produksi yang terhenti karena bahan baku yang tidak kunjung datang atau permasalahan lainnya.

Permasalahan kualitas produk di perusahaan ini tentu menjadi suatu nilai yang sangat penting, oleh sebab itu klasifikasi kualitas dari produknya dibagi menjadi beberapa bagian, yakni kualitas A/B, C, D, dan lost. Setiap kategori kualitas ini memiliki spesifikasi yang berbeda-beda berdasarkan adanya jenis defect tertentu. Terdapat banyak sekali jenis defect yang mungkin akan terjadi tetapi dari sekian banyak, perusahaan menetapkan terdapat 4 golongan, yakni defect iron spot, warp piece, bakar ulang (BU), dan other. Namun, pencapaian kualitas produk hanya dilihat dari kualitas A/B, C, D, dan lost saja tanpa memperhitungkan BU, karena hasil proses bakar ulang ini masih memungkinkan masuk kedalam kualitas $\mathrm{C}$ setelah dilakukan pekerjaan ulang. Walaupun jarang sekali ditemukan produk yang setelah dibakar ulang dapat mencapai kualitas A/B. 
Jenis defect iron spot merupakan jenis ketidaksesuaian yang terjadi dengan munculnya bintikbintik kandungan besi yang terperangkap, sehingga mengurangi nilai tampilan dari produk porcelain. Munculnya iron spot ini dapat terjadi ketika kandungan besi yang terdapat di lingkungan menempel pada produk. Kandungan besi ini bisa berasal dari bahan baku itu sendiri dan juga dari lingkungan sekitar. Jadi, ketika terdapat kandungan besi didalam produk setengah jadi (WIP), maka setelah dilapisi oleh glasur dan dibakar, kandungan besi itu akan muncul keluar. Jenis defect yang kedua ialah warp piece, yakni terjadinya perubahan bentuk yang tidak diinginkan, contohnya pada pinggiran piring yang jika diperhatikan tidak benar-benar berbentuk lingkaran. Biasanya defect ini disebabkan oleh kesalahan pemolesan yang kurang baik, pengaturan mesin, tingkat kekerasan bahan yang akan dibentuk, dan temperatur.

Bakar ulang disebabkan oleh tiga jenis cacat pada produk yang masih bisa ditambal ulang, yakni pin hole, body dip, dan retakan. Pin hole ialah munculnya lubang kecil karena ada udara yang terperangkap dalam lapisan glasur yang menyebabkan udara tersebut keluar menembus glasur. Body dip itu seperti kotoran kasar yang sudah mengeras dan menyatu pada sisi produk. Sedangkan retakan dapat berupa retakan tertentu yang dapat ditambal seperti retak handle pada produk gelas. Kedua hal ini masih dapat ditangani dengan cara menambal. Pin hole dan retakan tersebut ditambal dengan menggunakan lidi yang dilapisi glasur. Sedangkan untuk body dip, dilakukan gerinda pada kotoran tersebut, kemudian dilapisi lagi dengan glasur.

Kemudian jenis defect other terdiri dari beberapa jenis, seperti ame, hamakake, crack, curling, dan glasur gelombang. Ame ialah jenis cacat yang terjadi ketika suhu pembakaran tidak stabil, sehingga menyebabkan produk memiliki lapisan glasur yang mirip seperti kulit jeruk, dengan kata lain tidak mulus. Crack (retakan) dan hamakake merupakan cacat yang terjadi pada produk yang bersifat merusak produk tersebut sehingga tidak dapat digunakan lagi, seperti retak terbelah, adanya sisi yang hancur karena benturan dan lain hal. Sedangkan glasur gelombang dengan curling (glasur loncat, dimana lapisan glasur tidak meresap kedalam produk, sehingga ketika terjadinya pelelehan glasur, produk tidak seluruhnya terlapisi glasur), disebabkan oleh proses pelapisan glasur yang tidak merata.

Jika dilihat pada Gambar 2, akan terlihat jelas bahwa jenis defect yang dibakar ulang menjadi permasalahan yang paling banyak terjadi. Bakar ulang ini memberi kontribusi $48 \%$ dari keseluruhan defect yang ada dalam produksi. Dari hasil observasi lapangan, diperoleh bahwa jenis cacat pin hole dan retak handle gelas lebih banyak ditemui, bila dibanding body dip yang menyebabkan terjadinya bakar ulang tersebut. Produk gelas juga merupakan produk yang paling banyak jumlah variasi dan permintaannya. (Xiuli, Baozhi, \& Hanqing, 2012)

Kemudian, pada Gambar 3 dan Gambar 4 menunjukkan grafik peta kendali $p$. Dalam grafik ini menunjukkan kestabilan hasil suatu proses. Kedua grafik tersebut memperlihat jelas bahwa baik hasil proses produk WIP/barang setengah jadi dan produk barang jadi tidak terlihat stabil. Hal ini menunjukkan diperlukannya peningkatan akan kontrol dari keseluruhan proses yang mempengaruhi kualitas produk akhir.

Pada Gambar 3, terlihat bahwa angka defect produk WIP dapat mencapai angka tertinggi sebesar $10.71 \%$ dan paling rendah sebesar 6.63\% pada periode hingga November 2013. Hasil tingkat defect dari minggu ke minggu cenderung tidak stabil, artinya perubahan yang dialami naik atau turun cukup signifikan. Bahkan, tingkat defect yang dicapai cenderung keluar dari control limit, walaupun masih ada yang hampir masuk kedalam control limit, yakni pada minggu 6 sebesar 8.76\% dan minggu 14 sebesar 8.28 dengan control limit yang didapat $\pm 8.5 \%$ dan perusahaan sendiri menargetkan sebesar $6 \%$.

Selanjutnya pada Gambar 4, memperlihatkan grafik tingkat rata-rata defect produk barang jadi (glost ware) setiap minggunya dalam periode yang sama yang dapat mencapai angka paling tinggi hingga $11.6 \%$ dan paling rendah sebesar 5.96\%. Menariknya adalah pada hasil proses produksi produk 
glost ware ini cenderung meningkat walaupun ada juga yang turun. Hasil grafik ini juga menunjukkan bahwa kestabilan proses ini seolah-olah semakin lama semakin tidak terkendali, sehingga cenderung meningkat. Terdapat beberapa minggu yang cukup baik atau dapat dikatakan masih dalam batas yakni pada minggu 6 hingga minggu 14, kecuali pada minggu 10, dan 13 yang masih keluar dari batasan dengan rata-rata batasan $\pm 7.72 \%$ dari target perusahaan sebesar 6\% (Henley, Kumamota, 1992).

Produk yang tidak sesuai dengan kriteria pastinya memiliki banyak faktor yang menyebabkan ketidaksesuaiannya tersebut. Diagram fishbone pada Gambar 5 di bawah ini menunjukkan faktorfaktor yang akan mempengaruhi terjadinya defect produk. Ada 5 faktor utama, yakni mesin, lingkungan, metode, material, dan sumber daya manusia (people). Dari kelima faktor ini yang memiliki dampak yang cukup signifikan terjadinya defect ialah sumber daya manusia dan diikuti oleh faktor lingkungan, karena hampir keseluruhan proses yang dilakukan masih menggunakan tenaga manusia dari sortir produk hingga melakukan casting dan proses lainnya. Produk porcelain ini memang memiliki tingkat kesulitan yang cukup sulit dalam pembuatan sehingga membutuhkan ketelitian dan kepedulian setiap pihak dalam setiap proses pembuatannya dan harus terus menerus menjaga kebersihan tempatnya.

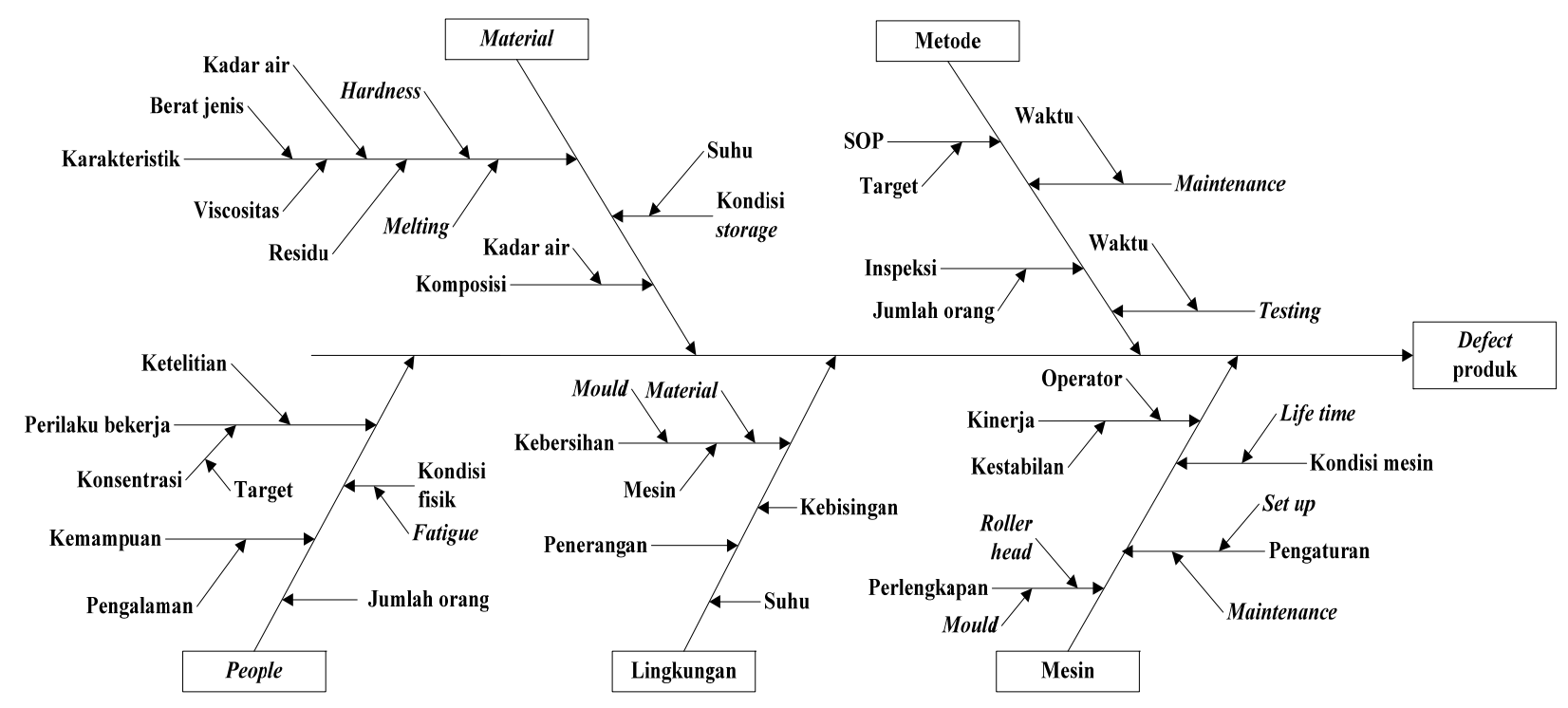

Gambar 5 Fishbone Diagram

Jika ditelusuri lebih dalam lagi dari 5 faktor besar yang terdapat pada diagram fishbone, tentunya terdapat hambatan-hambatan dalam mencapai produk yang berkualitas. Tabel di bawah ini menjelaskan secara singkat hambatan apa saja yang ada pada setiap faktor yang ada. (Besterfield, 2003) 
Tabel 4 Macam-macam Hambatan Berdasarkan Diagram Fishbone

\begin{tabular}{|c|c|}
\hline Faktor & Hambatan \\
\hline Material & $\begin{array}{l}\text { 1. Menjaga kualitas dan karakteristik bahan baku dari supplier. } \\
\text { 2. Mengatur komposisi bahan baku yang akan disatukan menjadi bahan utama } \\
\text { produk dan bahan lainnya seperti cetakan, dan pelapis glasur. } \\
\text { 3. Menjaga standar spesifikasi dari setiap proses, dari proses ball mill, press, } \\
\text { pembuatan cetakan, glasur, dst. } \\
\text { 4. Menjaga kestabilan karakteristik pada bahan baku tertentu yang dapat berubah } \\
\text { karena adanya proses penyusutan. }\end{array}$ \\
\hline Metode & $\begin{array}{l}\text { 1. Acceptance sampling ketika bahan baku sampai di gudang, guna menilai bahan } \\
\text { baku yang dipesan sesuai dengan kriteria yang diinginkan. } \\
\text { 2. Proses maintenance mesin yang harus selalu terkontrol. } \\
\text { 3. Proses inspeksi sampling yang perlu ditingkatkan dalam menentukan layak } \\
\text { dilanjutkan ke proses sebelumnya atau tidak pada proses pembakaran bisquit kiln. } \\
\text { 4. Testing terhadap kriteria bahan yang digunakan harus selalu terkontrol. } \\
\text { 5. Waktu penanganan masalah yang cukup lama untuk dapat ditelusuri. }\end{array}$ \\
\hline People & $\begin{array}{l}\text { 1. Rasa kepedulian tiap pekerja untuk saling menjaga kualitas produk pada setiap } \\
\text { prosesnya. } \\
\text { 2. Produktifitas yang harus dimaksimalkan dalam mencapai target produksi. } \\
\text { 3. Menjaga produktifitas yang mempengaruhi hasil target produksi. } \\
\text { 4. Kemampuan setiap orang yang beragam, sehingga mem-butuhkan pelatihan } \\
\text { keahlian tertentu dalam menjalankan tugas masing-masing bagian. } \\
\text { 5. Menjaga setiap pekerjaan yang dilakukan agar sesuai dengan SOP (standard } \\
\text { operating procedure) } \\
\text { 6. Kelengkapan pengaman yang memberikan kenyamanan pada pekerja dalam } \\
\text { melakukan pekerjaannya. }\end{array}$ \\
\hline Lingkungan & $\begin{array}{l}\text { 1. Lingkungan tempat kerja termasuk mesin dan berbagai peralatan yang harus selalu } \\
\text { dijaga kebersihannya. } \\
\text { 2. Kenyamanan tempat kerja pada setiap proses produksi yang mempengaruhi } \\
\text { produktifitas para pekerja. }\end{array}$ \\
\hline Mesin & $\begin{array}{l}\text { 1. Mesin yang digunakan terbilang sudah berumur, sehingga menyebabkan proses } \\
\text { maintenance dan kontrolisasi harus diperhatikan dan dikendalikan. } \\
\text { 2. Menjaga pengaturan mesin yang sering berubah dan kurang stabil. }\end{array}$ \\
\hline
\end{tabular}

Banyak faktor yang mempengaruhi kualitas produk sehingga diperlukan FTA (Fault Tree Analysis) untuk mengidentifikasi sebuah sistem yang gagal serta membantu untuk pengambilan keputusan dalam mendesain sistem keamanan dan kehandalan. Kejadian utama yang diambil ialah timbulnya masalah defect pada produk saat pembakaran akhir di glost kiln. Jika diperhatikan banyak kejadian yang sangat berkontribusi pada kegagalan sistem terkait kualitas produk yang dihasilkan seperti yang terlihat dari banyaknya or gate pada bagan FTA. Hal ini berarti hanya salah satu faktor saja yang dapat langsung mempengaruhi masalah defect. Hal ini menyebabkan penelusuran setiap masalah yang terjadi membutuhkan waktu yang cukup lama untuk mengidentifikasi penyebabnya. Proses produksi harus terus berjalan dan masalah sebelumnya masih belum dapat diselesaikan, hal ini akan memungkinkan datangnya permasalahan baru lagi yang menyebabkan permasalahan semakin membesar. (Vesely, 2002)

Berdasarkan hasil diagram pareto, permasalahan bakar ulang terlihat jelas menyebabkan terjadinya salah satu jenis defect yang ada. Permasalahan bakar ulang juga memiliki banyak kejadiankejadian yang menyebabkan terjadinya defect. Menariknya lagi, basic event (kejadian dasar) yang menyebabkan terjadinya bakar ulang disebabkan oleh faktor sumber daya manusia yaitu kebersihan perilaku operator dan prosedur standar operasional. Hal ini membuktikan bahwa kualitas harus dibangun dan dijaga dari awal hingga akhir, serta bukan hanya menjadi tugasnya bagian quality control, namun seluruh orang yang terlibat didalamnya, seperti yang sudah disebutkan sebelumnya. 


\section{SIMPULAN}

Dari hasil analisa pada pengolahan data dan perumusan masalah maka dapat disimpulkan bahwa faktor-faktor yang mempengaruhi terjadinya produk defect secara garis besar dipengaruhi oleh mesin, lingkungan, sumber daya manusia, metode, serta bahan baku sehingga dapat dilakukan perbaikan dan pencegahan pada hal-hal yang menjadi hambatan tersebut. Meskipun perusahaan sudah menerapkan standar ISO, namun dilihat dari hambatan-hambatan dan faktor-faktor yang menyebabkan permasalahan kualitas yang cukup kompleks, maka perlu ditingkatkan dari sisi pengendalian kualitas melalui pelatihan ISO yang berkelanjutan atau menggunakan metode-metode yang ada seperti sixsigma dan lean manufacturing guna mengurangi angka defect yang tinggi. Oleh karena itu, dengan menerapkan konsep dan metode ini, menjaga kualitas produk akan menjadi suatu budaya didalam perusahaan untuk terus menerus melakukan peningkatan (continuous improvement).

\section{DAFTAR PUSTAKA}

Administrator Siaran Pers. (2009). Produk Peralatan Makanan Rumah Tangga Mengandung Melamin Ancam Kesehatan Konsumen. Diakses 26 September 2013, dari humasbatam.com.

Besterfield, D. H. (2003). Total Quality Management. New Jersey: Pearson Education.

Henley, E. J., Kumamota, H. (1992), Probabilistic Risk Assessment: Reliability Engineering, Design and Analysis, New York: IEEE Press,

Montgomery, D. C. (2009). Introduction to Statistical Quality Control, Sixth Edition. United State of America: John Wiley \& Sons, Inc.

Myklebust. (2013). O. Zero Defect Manufacturing: A Product and Plant Oriented Lifecycle Approach. Procedia CIRP 12 (2013) 246 - 251.

Rungtusanatham, M. (2001). Beyond Improved Quality: The Motivational Effects of Statistical Process Control. Journal of Operations Management, 19(6): 653 - 673.

Vesely, B. (2002). Fault Tree Handbook with Aerospace Applications. Version 1.1. NASA HQ: NASA Publication.

Xiuli, L., Baozhi, C., \& Hanqing, X. (2012). Study on Principle of Product Defect Identification. Procedia Engineering, 43(2012), 393 - 398. 